\title{
Meeting the ecological challenge by Value Chain enlargement and enrichment
}

\author{
H. Hübner, Univ.-Prof. Dipl.-Ing. Dr. habil, head of \\ department Management Science - Technology Impact \& \\ Innovation Research (TWI), University of Kassel, \\ Nora-Platiel-Str. 4, D-34109 Kassel, Germany \\ Tel.: ++49-561-8043055 Fax: ++49-561-8043681 \\ e-mail: huebner@wirtschaft.uni-kasse.de
}

\begin{abstract}
During the past about 15 years, medium-sized and especially big companies in several branches have reduced the amount of manufacturing depth and, in this way, the Manufacturing Value Chain. This development was driven by strategic issues in the way of reduced costs and capital investment as well as increased flexibility. On the other hand, the responsibility of companies for their products has increased within that period: To meet the requirements of the new law on liability for products, changes in product design and quality management system have been implemented. Actually, the ecological responsibility of the company will increase: It is to be expected that the circulation economy and waste law passed by the German parliament in 1996 will become obligatory in the same sense at least for the EU member states. To meet this challenge, possibilities and necessities for extending the Manufacturing Value Chain are described. Finally, some results of a project on refrigerator design for easy disassembling and recycling are presented.
\end{abstract}

\section{Keywords}

Ecologically oriented corporate strategy, precaution measures, new understanding of the production system, product design for disassembling and recycling 


\section{PERSISTENT ECOLOGICALLY ORIENTED CORPORATE MANAGEMENT: FROM REPAIRING TO PRECAUTION}

\subsection{The need for a change}

Three quarters of all gases causing the greenhouse effect on Earth are produced by the industrialised states; the United States of America alone, having a share in the world population of $4 \%$, are blowing one quarter of the world's emission of $\mathrm{CO}_{2}$ into the air (Lohmeyer, 1997, p. IV). Facts of this kind meanwhile form the contents of entire documentations published by national ministries of environment, the World Watch Institute (Washington), the World Bank, and other institutions. In total, around $20 \%$ of the world population are responsible for $80 \%$ of the consumption of natural resources and related emissions. The main cause of this is the present economic system, established a mere 100 years ago and characterised by industrial production and mass consumption without heeding ecological limitations. Adopting this kind of economic activity for China alone, with a standard of equipment comparable to that of Western Europe (e.g. number of passenger cars and household appliances per 1000 inhabitants), would result in ecological collapse.

Therefore, re-orientation of economic activities and a change in the kind, direction, and goal of innovations is required. But environmental policy, as established in some countries and companies respectively, largely based on the principle of repairing, is not sufficient. To ensure the survival of mankind with adequate quality of life, the principle of precaution has to be applied.

\section{2 'Eco Audit' or more?}

The concept of 'environmental management' developed in the meantime (cp., among others, Malinsky, 1996, Winter, 1997) has also led to standards (DIN ISO 14001 and 14010, 1997) as well as the EMAS Ordinance of the EC (1993), which provides for voluntary eco-auditing and certification of the individual locations of a company. Even though this certification is helpful in competition, it will not be sufficient for the required ecological re-orientation: To express it oversubtly, the manufacture of products of insufficient ecological quality (see section 1.3) is possible even in certified operating locations. This is caused, above all, by a 'strategic deficit' (Dyllik/Hummel, 1995), as well as extensive neglecting of a product-related consideration (particularly with EMAS).

Reducing the strategic deficit will require embedding of ecological orientation in the corporate strategy, i.e. in the corporate vision, as an 'ambitious dream of changing the environment' and an instrument of management in order to introduce new values (Hinterhuber, 1996, pp. 83 \& seq.) into the company. Oriented on the normative approach of 'Sustainable Development' (World Commission, 1987, p. 43), 
- considerate handling of natural resources (raw materials and stocks obtained from these, energy, water, air, etc.) as 'inputs' for manufacture, utilisation, and disposal, as well as

- minimising or preventing emissions (as 'outputs') in consideration of the limited absorbing capacity of the environmental media should be laid down as strategic guidelines for concrete action.

\subsection{Product-related measures to increase ecological quality}

To identify potential ecological weak points, the (relative) ecological quality of the product as a basis for required measures has to be determined. This may be understood as a totality of the partial qualities which have to be determined specifically for each phase of a holistic product life cycle. A possibility of graphical presentation of the result of such determination is shown in Figure 1. Obviously, it will not be possible to obtain a total quality by simple aggregation of partial qualities. As can be seen from Figure 1, a scale is used to assess the partial qualities, reaching from -5 for unacceptable ecological partial quality, e.g. due to long-term irreversible harm to nature, to +5 for very good ecological quality.

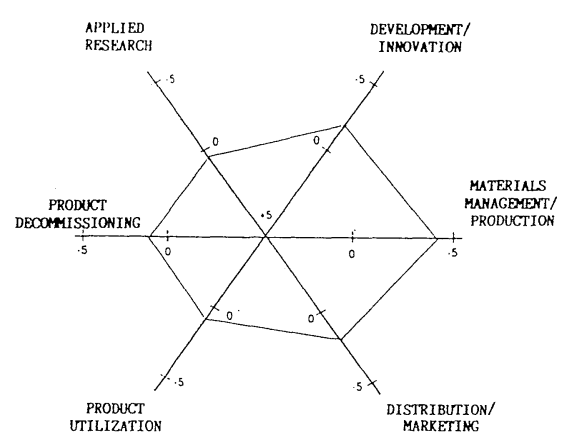

Figure 1 Ecological quality of a product as determined by its partial qualities (example) (cp. Hübner/Simon-Hübner, 1991, p. 56).

Applying the holistic product life cycle, the ecological quality of production, including materials management, is considered as a partial quality of the product. This approach ensures to consider not only ecological impacts of production processes of the individual company, but also the amount of production-related waste - which may be 10 to 50 times higher than the weight of the product - and all resources required for getting materials, beginning with their extraction from raw materials.

All these resources are burdening the product as an ecological 'Rucksack'. The aim of measures following the principle of precaution is to reduce the use of new resources along with unchanged benefit of the product to the customer. This reduction of resource input involves a reduction of emissions and 
production-related waste and will, in this way, lead to an increase of resource efficiency. Further statements are concentrating on the respective possibilities and consequences for (the strategic management of) the Manufacturing Value Chain.

\section{MEASURES FOR INCREASING RESOURCE EFFICIENCY AND CONSEQUENCES FOR THE STRATEGIC MANAGE- MENT OF THE MANUFACTURING VALUE CHAIN}

Preoccupation with the 'input' side for the phases of production, utilisation, and 'decommissioning' of products under ecological aspects has been coming up only in recent years with a view to restricted dumping capacity for 'old' products, increased resistance in the population against further dumping sites and refuse incineration plants, and also to international agreements on reduction of greenhouse gas emissions. These latter directly depend on the volume of materials used, energy input for obtaining raw materials, transport, etc. Estimates for increasing resource efficiency without losses in quality of life range between a factor of 4 (Weizsäcker/Lovins, 1995) and 10 (Schmidt-Bleek, 1994). Since examples of greater factors meanwhile exist, the TWI Product Workshop bears the designation 'Factor $\mathrm{x}^{\prime}$.

\subsection{Measures for increasing resource efficiency}

Possible measures for increasing resource efficiency are concerning the quantity as well as the speed of resource flows.

Measures for reduction of quantity are concerning, above all, the substitution of resource-intensive technologies. Several tools have meanwhile been developed for recording of resource intensity; as examples, MIPS (Material Intensity Per Service Unit, cp. Schmidt-Bleek, 1993) and Cumulative Energy Demand (VDI 4600) may be named.

However, measures for reduction of speed are also linked to quantity reduction. Dealing with speed, attention will be directed to the factor of time: Measures for reduction of speed are based on the 'Longevity Approach' (LA), which may be applied to products and product components.

The aim of LA application for products is to increase the duration of product utilisation by means of product-related services ranging from maintenance and repair to technical updating and upgrading. This extension of the traditional Manufacturing Value Chain may be designated as 'value adding for value preservation' of the product. A more detailed description of the LA and a case study demonstrating the economic reasonability of product reconditioning, too, is described by Hübner (1998).

By application of the LA, the phase 'after the end of utilisation' will be reached later. Since the company will be responsible also for that phase in 
future (Kreislaufwirtschafts- und Abfallgesetz, 1996), it will have to deal with the respective measures, irrespective of whether these will be carried out in the company itself or outside of it. Additional value adding concerns re-utilisation of components (LA) and various forms of recycling.

Product design providing for easy disassembly will be a prerequisite. The results of a related project are presented in chapter 3 .

\subsection{Consequences for strategic management of the Manufacturing Value Chain}

Summing up, Figure 2 shows possibilities and necessities respectively for extending the Manufacturing Value Chain to meet ecological requirements, leading to a new understanding of the production system.

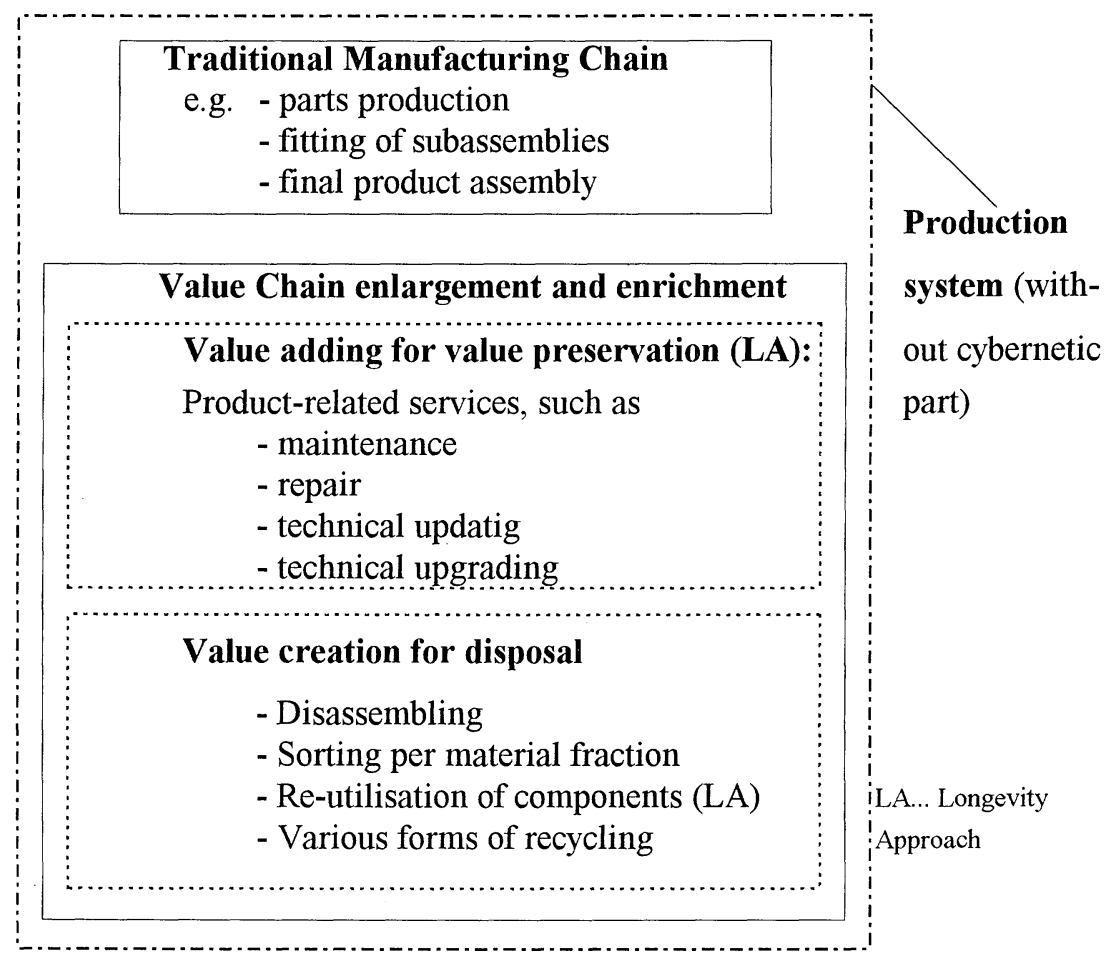

Figure 2 New understanding of production system meeting ecological requirements. AND RECYCLING

Selected results of a project worked out together with a company (cp. Hübner et al., 1997) are being presented below (Figures 3 to 5). Units of various makes as 
well as of different manufacturing years from one manufacturer were examined as to their suitability for disassembling, separability of material fractions, and recyclability. The products were disassembled completely in the 'Factor $x^{\prime}$ TWI Product Workshop and compared in respect of product characteristics (weight, number of parts, kind and number of different materials used), disassembling time, time-weight diagrams (which handling equipment is necessary for disassembling?), kind and number of different connecting techniques, total number of connecting points, portion of components that may be disassembled without destruction, and other criteria.

The aim was to derive concrete requirements for new product development in order to meet ecological requirements as well.
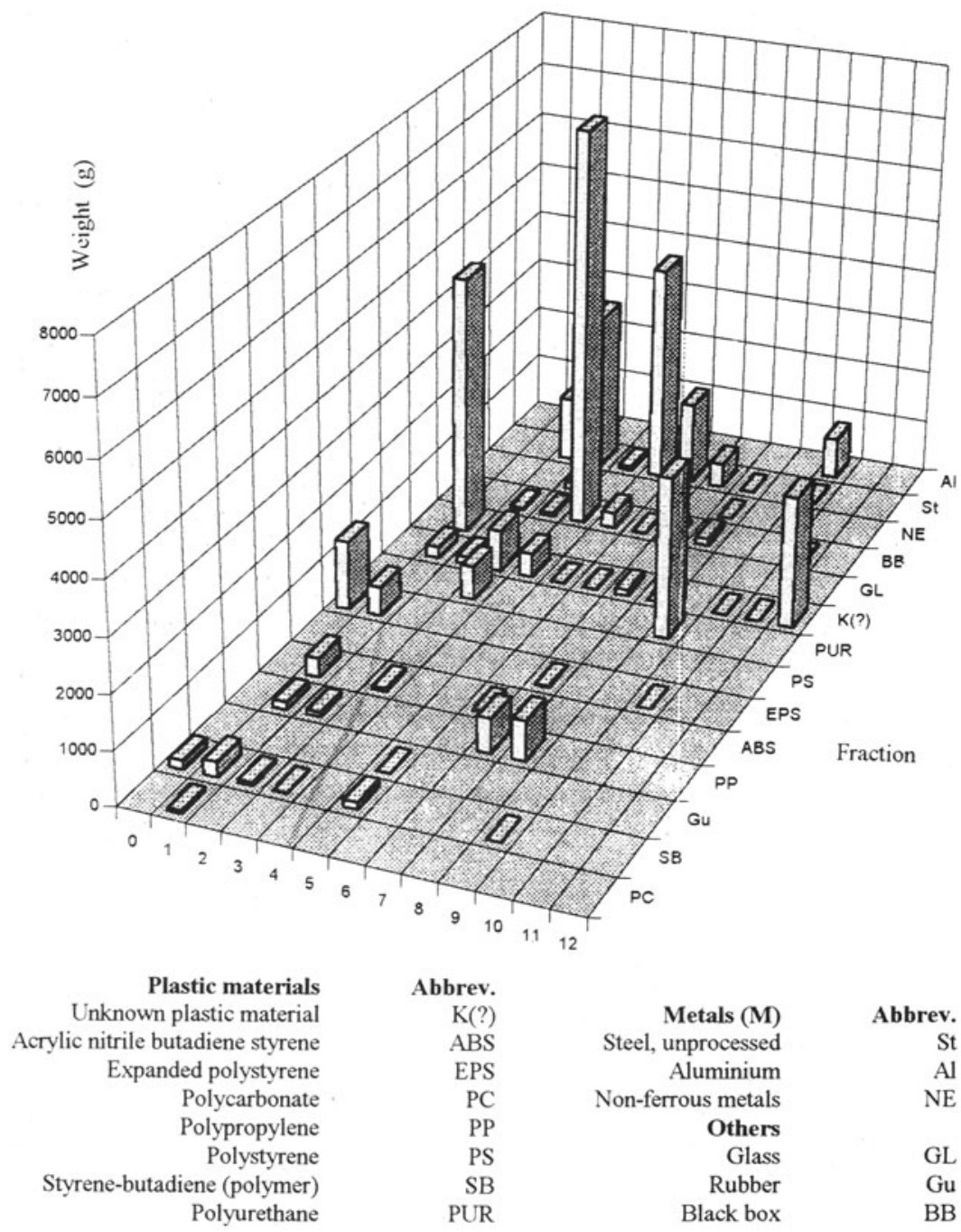

$\begin{array}{rrr}\text { K(?) } & \text { Metals (M) } & \text { Abbrev. } \\ \text { ABS } & \text { Steel, unprocessed } & \text { St } \\ \text { EPS } & \text { Aluminium } & \text { Al } \\ \text { PC } & \text { Non-ferrous metals } & \text { NE } \\ \text { PP } & \text { Others } & \\ \text { PS } & \text { Glass } & \text { GL } \\ \text { SB } & \text { Rubber } & \text { Gu } \\ \text { PUR } & \text { Black box } & \text { BB }\end{array}$

Figure 4 Weight shares per mat. fraction and disassembling level for Unit 1. 
Disassembly Unit 1

Unit 2

Unit 3

\begin{tabular}{|l|c|c|c|}
\hline Number of components & 153 & 191 & 131 \\
\hline Time for disassembling (sec) & 2797 & 2937 & 4098 \\
\hline Time for cleaning (sec) & 2118 & 1405 & 1650 \\
\hline Total weight (grams) & 36844 & 41062 & 35651 \\
\hline Number of joints & 153 & 182 & 102 \\
\hline Number of joining points & 258 & 203 & 182 \\
\hline
\end{tabular}

Figure 3 Comparison of three units by means of selected criteria

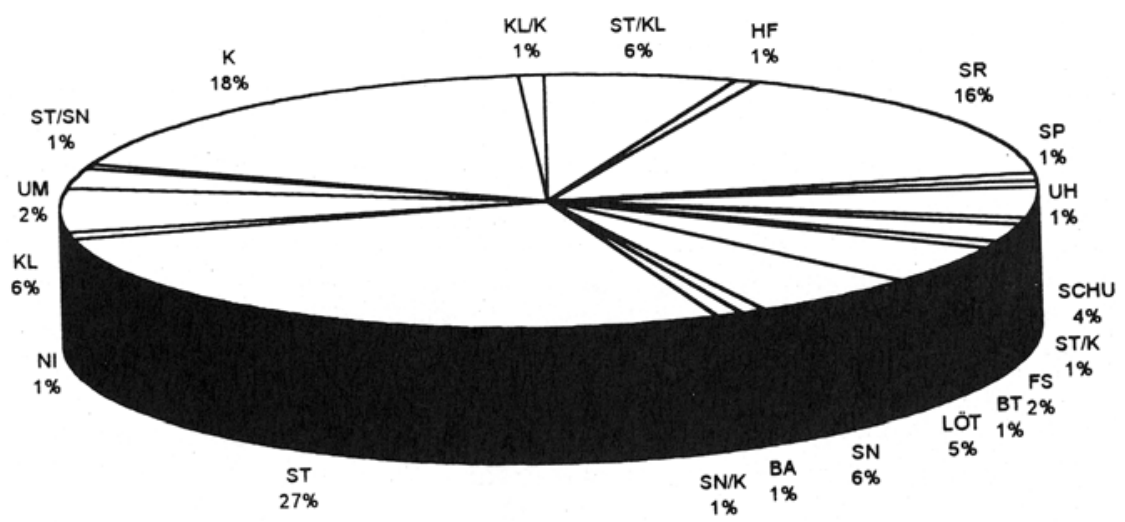
plug-in/clamping joint $\mathrm{ST} / \mathrm{KL}$ slide-in joint SCHU screw/bolt joint SR glued joint $\mathrm{K}$ clamping joint $\mathrm{KL}$ encasing $\mathrm{UH}$ inserting joint EIN
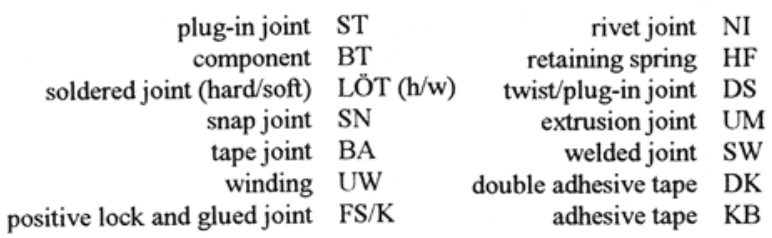

Figure 5 Joining techniques of Unit 1.

\section{REFERENCES}

DIN Deutsches Institut für Normung (1995) DIN ISO 14001 Umweltmanagementsysteme, and DIN ISO 14010 Allgemeine Grundsätze für die Durchführung von Umweltaudits, drafts, Berlin

Dyllik, T./Hummel, J. (1995) EMAS und/oder ISO 14001 - Wider das strategische Defizit in den Umweltmanagementnormen, in UmweltWirtschaftsForum (UWF) Nr. 3, pp. 24-28

EMAS (Environmental Management and Audit Scheme) (1993), Verordnung (EWG) Nr. 1836/93, Amtsblatt der Europäischen Gemeinschaft Nr. L 168 
Hinterhuber, H.H. (1996) Strategische Unternehmungsführung, vol. I: Strategisches Denken, 6th. edn., Berlin et al.

Hübner, H. (1998) The ecology-driven service (r)evolution - The product longevity approach..., in Advances in Production Management Systems Perspectives and Future Challenges (eds. Okino, N./Tamura, H./Fujii, S., Chapman \& Hall, London, pp. 255-266

Hübner, H./Lehmann, F./Hübner, H./Lehmann, F./Grimm, F./Kube, J./Miltner, W. (1997) Gestaltung von Kühl- und Gefriergeräten unter Berücksichtigung ökologischer Anforderungen, Report No. 5 from the 'Faktor x' TWI Product Workshop, University of Kassel

Hübner, H./Simon-Hübner, D. (1991) Ökologische Qualität von Produkten. Ein Leitfaden für Unternehmen, Hessisches Umweltministerium (Hrsg.), Wiesbaden/TWI, University of Kassel, ISBN 3-89274-061-5.

Kreislaufwirtschafts- und Abfallgesetz: Gesetz zur Vermeidung, Verwertung und Beseitigung von Abfällen (1996) 27 Sept, Bonn

Lohmeyer, M. (1997) Unter den Wolken, in Die Presse, SPECTRUM, 29 Nov., p. IV, Wien

Malinsky, A.H. (ed.) (1996) Betriebliche Umweltwirtschaft. Grundzüge und Schwerpunkte, Wiesbaden

Schmidt-Bleek, F. (1993) Wieviel Umwelt braucht der Mensch? MIPS - das Maß für ökologisches Wirtschaften, Basel et al.

Schmidt-Bleek, F.(1994) Carnoules Declaration. Factor 10 Club, Wuppertal

VDI (1997): VDI-Richtlinie 4600: Kumulierter Energieaufwand - Begriffe, Definitionen, Berechnungsmethoden, Berlin

Weizsäcker, E.U.v./Lovins, A. \&. H. (1995) Faktor Vier. Doppelter Wohlstand halbierter Naturverbrauch, Report to the Club of Rome, München

Winter, G. (ed.) (1997) Ökologische Unternehmensentwicklung. Management im dynamischen Umfeld, Berlin et al.

World Commission on Environment and Development (ed.) (1987): Our Common Future, Oxford et al.

\section{BIOGRAPHY}

Heinz Hübner: After 10 years industry employment, academic career in Austria, appointments at University of Innsbruck and Institute for Advanced Studies in Vienna, research activities at the International Institute for Applied Systems Analysis (IIASA), Laxenburg near Vienna. Main fields of interest: economic, social, and environmental impact of technological change. Introduction and scientific responsibility for interdisciplinary studying course 'Innovation Management, considering Technology \& Product Impact Assessment.' Author of Informationsmanagement (München, 1996), co-author of Transrapid zwischen Ökonomie und Ökologie (1997), numerous journal articles and contributions to collective volumes, editor of The Art and Science of Innovation Management (Elsevier, 1986), co-editor of Innovation Strategies, Theoretical Approaches - Experiences - Improvements (Elsevier, 1992) and Recent Essentials in Innovation Management and Research (Gabler, 1995). Member of Editorial Board of Technovation. 